AC 2010-222: STRENGTHENING THE U.S. ENGINEERING WORKFORCE FOR INNOVATION: FOUNDATIONS OF PROFESSIONAL GRADUATE EDUCATION FOR THE NATION'S ENGINEERS IN INDUSTRY - PART III SENIOR CAREER DEVELOPMENT: STRATEGIC LEADERSHIP

Norman Egbert, Rolls-Royce Corporation 
GSD-2010-1455-Abstract \#3

Invited Panel Session

Professional Graduate Engineering Education \& Industry

ASEE-2010 Annual Conference

\title{
Strengthening the U.S. Engineering Workforce for Innovation: Foundations of Professional Graduate Education for the Nation's Engineers in Industry - Part III Senior Career Development: Strategic Leadership -
}

\begin{abstract}
This is the third of four invited panel papers prepared specifically for the National Collaborative Task Force Engineer-Leaders Project. The Project concerns the deliberate advancement of professional graduate engineering education relevant to the needs of creative engineering practice in industry to enhance U.S. technological innovation and competitiveness. The strength of the innovation and leadership capacity of America's professional engineering base in our civilian, aerospace, and defense industries is a critical asset in our global economic recovery. As with other learned professions, there are progressive skill-sets and actions that must be learned or developed at the advanced levels of the practice of engineering. This series of papers addresses the skills continuum in three main parts: a) Part I addresses the Direct Leadership Skills and Actions required for Engineering Levels [1-3]; b) Part II addresses the Organizational Leadership Skills and Actions required for Engineering Levels [4-6], and; c) Part III addresses the Strategic Leadership Skills and Actions required for Engineering Levels [7-9]. The overall analysis sets the foundation for building a coherent professional graduate curriculum and dynamic educational process reflective of how experienced engineering professionals learn, grow, and create new technology in industry. This paper addresses Part III: the Strategic Leadership Function, Skills and Actions that the engineer must learn and develop at Director of Engineering, Chief Engineer, and Vice President of Engineering Levels [7-9].
\end{abstract}

